\section{Commentary: Show me the data}

\author{
Ryan P. Plichta, MD, and Edward P. Chen, MD
}

In the recently released 2020 American Heart Association/ American College of Cardiology Guideline for the Management of Patients With Valvular Heart Disease, we are again provided with a framework to guide clinical practice and deliver quality care. ${ }^{1}$ The task of providing global recommendations - derived ideally from the best available evidence-is both daunting and monumental. Given the vast range of resources available in the world, it is challenging to find a one-size-fits-all approach.

We commend the Latin American Association of Cardiac and Endovascular Surgery (LACES) for their careful consideration and adoption of guidelines to help surgeons navigate and provide optimal care while considering the socioeconomic structure of their society. ${ }^{2}$ It is our opinion that they have taken an open, unbiased view that is completely patient-centric. Guidelines, if not properly supported by available evidence, can put undue stress on health care systems and surgeons, especially when facing realities of economic disparity. LACES further emphasizes that designating a class of recommendation (COR) I based on level of evidence (LOE) A may be debatable when considering the large randomized controlled trials (RCTs) on which these recommendations were based.

One example involves RCT data examining transcatheter aortic valve implantation (TAVI) based on patient risk profiles. ${ }^{3-6}$ The new COR I uses patient age as the main driver for decision making. The claim that COR I was made on LOE A is not supported by LACES and appears to be a legitimate concern.

The authors also point out that the broad definitions of high risk do not appear to be derived from big data logistic regression analyses, which could result in overestimation of risk and recommendations for treatments not showing superiority. TAVI was ultimately found to be noninferior

\footnotetext{
From the Division of Cardiovascular and Thoracic Surgery, Duke University Medical Center, Durham, NC.

Disclosures: The authors reported no conflicts of interest.

The Journal policy requires editors and reviewers to disclose conflicts of interest and to decline handling or reviewing manuscripts for which they may have a conflict of interest. The editors and reviewers of this article have no conflicts of interest.

Received for publication Feb 18, 2021; revisions received Feb 18, 2021; accepted for publication Feb 19, 2021; available ahead of print Feb 27, 2021

Address for reprints: Edward P. Chen, MD, Division of Cardiovascular and Thoracic Surgery, Duke University Medical Center, DUMC 3442, Durham, NC 27710 (E-mail: edward.p.chen@duke.edu).

J Thorac Cardiovasc Surg 2021;162:587-8

0022-5223/\$36.00

Copyright (c) 2021 by The American Association for Thoracic Surgery

https://doi.org/10.1016/j.jtcvs.2021.02.083
}

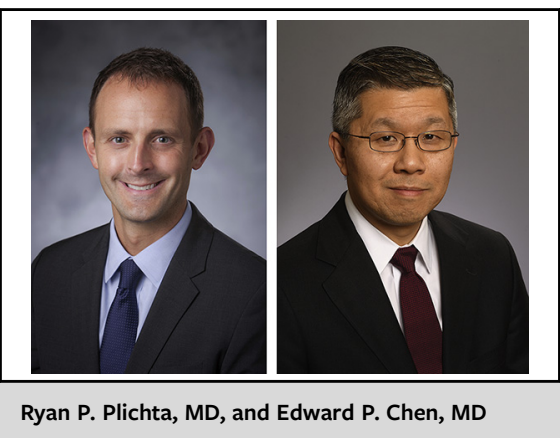

CENTRAL MESSAGE

The Latin American Association

of Cardiac and Endovascular

Surgery presents a compelling

argument about the need for

evidence-based guidelines and

consideration for socio-

economic realities.

to surgical aortic valve replacement in high-risk patients and yet the new guidelines recommend transfemoral TAVI or palliation only for both high- and prohibitiverisk patients. According to the authors, this should be amended to include surgical consideration in high-risk patients.

The TAVI RCT lack data for long-term safety and durability, and given the known detrimental effects of paravalvular leak and pacemaker implantation, we agree with LACES that it is hard to support a COR I recommendation for TAVI in patients with a life expectancy $>5$ years.

Lastly, when considering mitral valve interventions in patients with functional mitral regurgitation and the results of several RCTs, a COR IIA for transcatheter edge-to-edge repair or giving transcatheter edge-to-edge repair a higher level of recommendation than surgery, does not appear to be supported by the LOE designation or data. ${ }^{7-9}$

We congratulate the LACES authors for their unbiased, evidence-based, patient- and surgeon-centric objections. It should be expected that societies and their members look at these recommendations and ultimately decide on an individualized optimal approach based on available resources and local infrastructure. Above all, when strong recommendations are made on a such a broad level, it is imperative that they be supported by evidence-based data.

\section{References}

1. Otto CM, Nishimura RA, Bonow RO, Carabello BA, Erwin JP III, Gentile F, et al 2020 ACC/AHA guideline for the management of patients with valvular heart 
disease: executive summary: a report of the American College of Cardiology/ American Heart Association Joint Committee on clinical practice guidelines. Cir culation. 2021;143:e35-71.

2. Dayan V, Garcia-Villarreal OA, Escobar A, Ferrari J, Quintana E, MarinCuartas M, et al. The Latin American Association of Cardiac and Endovascular Surgery statement regarding the recently released American Heart Association/ American College of Cardiology Guidelines for the Management of Patients With Valvular Heart Disease 2020. J Thorac Cardiovasc Surg. 2021;162:584-6.

3. Smith CR, Leon MB, Mack MJ, Miller DC, Moses JW, Svensson LG, et al. Transcatheter versus surgical aortic-valve replacement in high-risk patients. $N$ Engl J Med. 2011;364:2187-98.

4. Leon MB, Smith CR, Mack M, Miller DC, Moses JW, Svensson LG, et al. Transcatheter aortic-valve implantation for aortic stenosis in patients who cannot undergo surgery. N Engl J Med. 2010;363:1597-607.
5. Leon MB, Smith CR, Mack MJ, Makkar RR, Svensson LG, Kodali SK, et al. Transcatheter or surgical aortic-valve replacement in intermediate-risk patients. N Engl J Med. 2016;374:1609-20.

6. Popma JJ, Deeb GM, Yakubov SJ, Mumtaz M, Gada H, O'Hair D, et al. Transcatheter aortic-valve replacement with a self-expanding valve in low-risk patients. $N$ Engl J Med. 2019;380:1706-15.

7. Stone GW, Lindenfeld J, Abraham WT, Kar S, Lim DS, Mishell JM, et al. Transcatheter mitral-valve repair in patients with heart failure. N Engl J Med. 2018;379:2307-18.

8. Obadia JF, Messika-Zeitoun D, Leurent G, Iung B, Bonnet G, Piriou N, et al. Percutaneous repair or medical treatment for secondary mitral regurgitation. $N$ Engl J Med. 2018;379:2297-306.

9. Feldman T, Kar S, Elmariah S, Smart SC, Trento A, Siegel RJ, et al. Randomized comparison of percutaneous repair and surgery for mitral regurgitation: 5-year results of EVEREST II. J Am Coll Cardiol. 2015;66:2844-54.
See Article page 584.

Commentary: American Heart Association/American College of Cardiology Valve guidelines: Starting point for discussion by the heart team or dictum?

\author{
J. James Edelman, MBBS(Hons), $\mathrm{PhD},{ }^{\mathrm{a}}$ and \\ Vinod H. Thourani, MD ${ }^{\mathrm{b}}$
}

We read with interest the position statement of the Latin American Association of Cardiac and Endovascular Surgery (LACES) regarding the recently released American Heart Association/American College Cardiology Guideline for the Management of Patients With Valvular Heart Disease. $^{1,2}$ The LACES disagrees with a number of the guideline recommendations for the use of surgical aortic valve replacement (SAVR) or transcatheter aortic valve replacement (TAVR) for aortic stenosis and edge-to-edge

From the ${ }^{\mathrm{a}}$ Department of Cardiothoracic Surgery, Fiona Stanley Hospital, Perth, Australia; and ${ }^{\mathrm{b}}$ Department of Cardiovascular Surgery, Marcus Valve Center, Piedmont Heart Institute, Atlanta, Ga.

Disclosures: Dr Thourani Advisor/Research: Abbott Vascular, Boston Scientific, Cryolife, Edwards Lifesciences, Jenavalve. Dr Edelman reported no conflicts of interest.

The Journal policy requires editors and reviewers to disclose conflicts of interest and to decline handling or reviewing manuscripts for which they may have a conflict of interest. The editors and reviewers of this article have no conflicts of interest.

Received for publication Feb 17, 2021; revisions received Feb 17, 2021; accepted for publication Feb 18, 2021; available ahead of print Feb 27, 2021.

Address for reprints: Vinod H. Thourani, MD, Department of Cardiovascular Surgery, Piedmont Heart Institute, 95 Collier Rd, Suite 5015, Atlanta, GA 30308 (E-mail: vinod.thourani@piedmont.org).

J Thorac Cardiovasc Surg 2021;162:588-90

$0022-5223 / \$ 36.00$

Copyright (c) 2021 by The American Association for Thoracic Surgery

https://doi.org/10.1016/j.jtcvs.2021.02.080
Check for updates

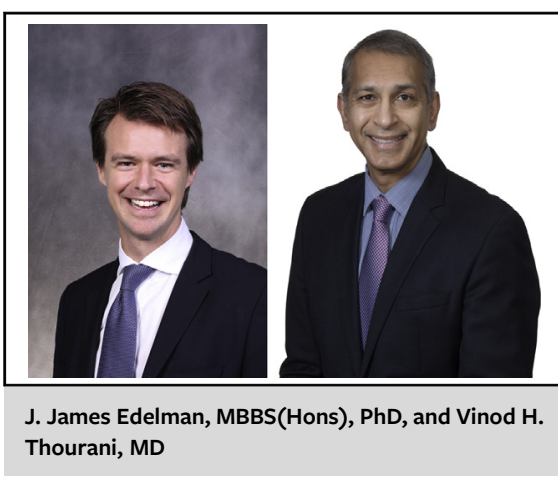

CENTRAL MESSAGE

The guidelines highlight the need

for shared decision making

among patients, surgeons, and

cardiologists that must focus on

a patient's anatomic factors, life

expectancy, and preferences.

repair for functional mitral regurgitation (FMR). We congratulate the LACES group for such a passionate letter regarding the management of valve disease and believe that this discussion is extremely timely.

\section{AORTIC STENOSIS}

The randomized trials comparing SAVR with TAVR have been the most rigorous investigation performed of any valve trials in history with more than 10,000 patients studied with independent Data Safety Monitoring Boards, Clinical Events Committees, and core-laboratory adjudicated echocardiography. ${ }^{3-9}$ These trials were performed in 3 cohorts of high-, intermediate-, and low-risk patients and overall have 